\title{
Corporate income tax and the international challenge*
}

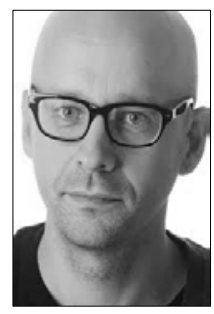

Benn Folkvord University af Stavanger

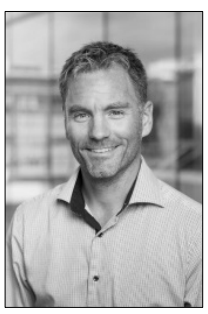

Michael Riis Jacobsen

Confederation of

Norwegian Enterprise

General report to the NTRC-seminar, Eidsvoll May 22. - 23. 2014

Abstract: Although globalization has contributed immensely to growth and prosperity around the world, it is a growing challenge for tax policy makers. Globalization and greater mobility of tax bases increase the relative importance of taxes in corporations' investment decisions. The combination of highly mobile capital, inadequacies in existing tax laws and a total change of international business environment have led to the fundamental problem in international tax law labeled by the OECD as the problem of BEPS (Base Erosion and Profit Shifting), along with severe competition among countries to attract investments and business activities. These challenges are the topic for the 2014 seminar of the Nordic Tax Research Council. Based on the Nordic national reports we discuss these challenges.

Keywords: Corporate Tax, Globalization, Tax competition, BEPS, GAAR, SAAR

* The authors would like to thank the national raporteurs for providing necessary input to this report. We have also benefited greatly from comments from Diderik Lund, Marie Bjørnebye, Thomas Klev and other participants at the NTRC seminar at Hurdalsjøen. The report reflects the views of the authors only and can not be attributed to any organisation. Any errors related to facts or theory in this report are the sole responibility of the authors. 


\section{Introduction}

A higher degree of cross-border integration has challenged the international corporate tax framework. Tax competition due to increased capital mobility and international profit shifting by multinational enterprises have put pressure on national corporate tax bases and weakened the states' sovereignty over their domestic tax systems. During the last decades, the corporate tax rates have been lowered throughout the OECD and also in the Nordic countries. This means that the topic "Corporate taxation and the international challenges" is more relevant now than in decades.

The national reports shows that this is a great concern in the Nordic countries, and most of the Nordic countries are revising and introducing anti-avoidance provisions. However, corporate tax challenges are not a Nordic problem in particular, although it can be argued that the Nordic countries are particularly vulnerable due to relatively high taxes. However, the intense work in OECD known as the BEPS project (Base Erosion and Profit Shifting) makes it clear that these challenges are global.

Common Nordic and global challenges are tax avoidance through the use of hybrid entities, hybrid instruments, tax treatment of related party debt financing, transfer pricing and different types of treaty abuse. Although measures have been taken, many of the Nordic antiavoidance provisions often seem quite complex or ineffective.

The corporate tax rates have recently been reduced in the Nordic countries, with the exception of Iceland where the tax rate was increased after the financial crisis. The corporate tax rates in all the Nordic countries are currently below the OECD average, except for Norway.

The topic "Corporate taxation and the international challenges" is highly relevant, which is demonstrated by several Nordic committees working on, or recently having worked on, revising the national corporate tax. There is a Corporate Tax Committee due to present a proposal in both Norway and Sweden in 2014. According to the mandate of both Committees, they will propose changes to the legislation to protect the tax base in an increasingly globalized world. In Finland, a working group proposed a moderate shift from corporate income taxation to personal-level capital income taxation. The working group also considered transferring the revenue share of corporate income tax from municipalities to the central government. 


\section{Globalization}

What is globalization, and why do we need to be concerned about globalization when designing our tax systems? International trade has been around for thousands of years. Products and ideas were exchanged through the silk road that connected Asia, Europe and Africa in the old world, and international trade has grown ever since with new means of transportation by sea, railways, roads and air traffic. In the $20^{\text {th }}$ century the world witnessed an explosion in the mobility of goods, capital and people. Physical mobility along with the telecommunication revolution has compressed time and space and accelerated the process of global interchange.

Only the last 20 years, after the big tax reforms in the Nordic countries in the beginning of the nineties, the world has been turned upside down by the cyber revolution. From being more or less nonexistent when the Nordics founded the fundamental principles of our tax systems, internet and mobile phones now dominate the way we interact, connecting billions of people worldwide virtually without time restraints. No one can tell the future, but it would be ignorant to expect the process of globalization to cease or even to slow down in the near future. The challenge is to design tax systems that can maintain robustness, fairness and efficiency in a world that will continue to change with an exponential speed. This is not an easy task.

Globalization has contributed immensely to growth and prosperity around the world. According to OECD, international trade in goods and services has almost tripled and cross border investment has multiplied many times since 1995 (figure 1). There is no doubt that increased trade, cross border investments, mobility of production factors and the exchange of technology lead to a higher world output. On the other hand, there are a lot of concerns in the wake of globalization and increased production, as how to distribute welfare, how to preserve the environment and the climate, how to regulate international business and among a lot of others things; how to tax international mobile production factors and international mobile profit.

This has led to a growing challenge for tax policy makers. The need to eliminate international double taxation has been agreed upon at least since the birth of the OECD model tax convention more than half a century ago, and measures to avoid overlapping taxation have since been an important part of tax treaties and domestic tax laws.

Greater mobility of tax bases increases the relative importance of taxes in corporations' investment decisions. Along with legal measures to avoid double taxation, the problem of international double non-taxation has gradually emerged. The combination of highly mobile capital, inadequacies in existing tax laws and a total change of 
international business environment have led to the fundamental problem in international tax law labeled by the OECD as the problem of BEPS, along with severe competition among countries to attract investments and business activities.

For a long time it has been a well-known fact in economic tax literature that a source based tax on mobile production capital cannot be part of an optimal tax scheme. The corporate income tax is severely challenged by international profit shifting and tax competition and the challenges are mainly fuelled by increased capital mobility. However, during the wave of tax reforms in the late 80 's and 90 's, one could easily observe that capital mobility was far from perfect, and for a number of reasons (like home biased investors, access to productsand labor markets, political environment, infrastructure etc.) the source based business taxation survived.

Since the beginning of the 1990's, the international business environment has changed. International trade and cross-border investments have accelerated the last 10-15 years. International business structure is more dominated by large multinational enterprises,

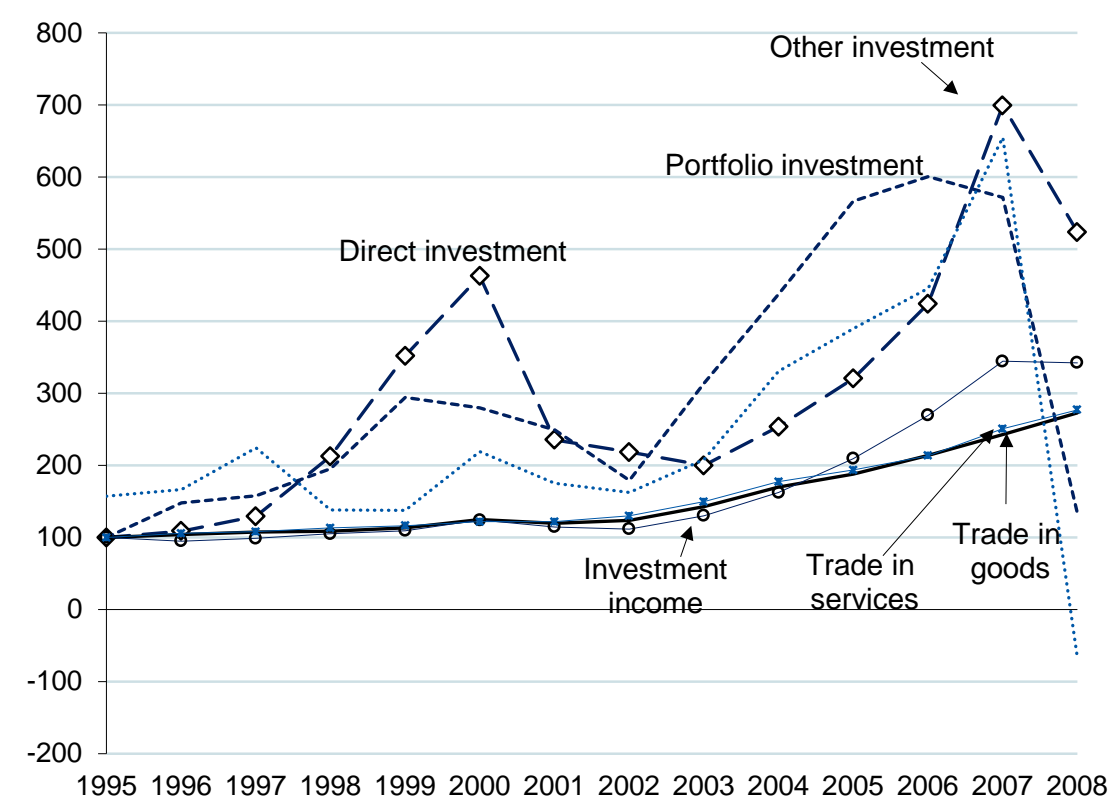

Figure 1: Trends in international trade and investment components, OECD, current prices $1995=100$

Source: $\mathrm{OECD}$

often characterized by vague or absent permanent establishment status which makes it difficult to determine the correct tax jurisdiction, 
and the use of a range of profit shifting measures minimize the overall tax burden. The emergence of the borderless digital economy is challenging the traditional connection between where the taxable income is earned and where the production factors are located. It is no longer just a question of how countries are going to divide tax revenues between them with the aid of a tax treaty. A tax treaty is not very helpful if a clearly profitable corporation seemingly has no taxable activity, at least not in a place where it is subject to taxation.

The tax reforms of the late eighties and early nineties were based on tax rate cuts combined with base broadening. This approach revitalized the corporate and capital income taxation and it seems to have improved the allocation of resources and even tax revenues in several OECD-countries. 20 years later it seems that concerns about BEPS and tax competition have replaced some of the concerns about neutrality and domestic resource allocation. Following the OECD study "Tax Policy Reform and Economic Growth (OECD 2010)", a growth oriented tax reform might rather be based upon a shift of the tax burden away from the corporate income tax towards tax bases that are less harmful to growth, like consumption or immovable property. Underneath this lies the assumption that the corporate income tax is the form of taxation most harmful to growth.

This seems to be a decisive period in time for the corporate income tax, and we are left with a range of important questions that needs to be dealt with in the years to come. Will the BEPS process succeed and reach a consensus based "rescue pack" for the corporate income tax, or will it lead to an even more complex and incomprehensive international tax environment, with an even larger scope of income shifting opportunities and increased costs of taxation? Do we have available corporate income tax models from economic literature to deal with the challenges from increased internationalization and capital mobility? Do we need international tax consensus to deal with the problems like a harmonization of tax bases across countries? Will the road ahead be to shift the tax burden away from corporate income tax towards less harmful tax bases? We are not able to answer these questions in this report, but hopefully the report will contribute to some insight to the current challenges of Nordic corporate tax policy.

\section{Rules that act as incentives for investment}

All the Scandinavian countries do to some extent have rules that act as incentives for investments.

In Denmark, development activities related to the taxpayer's business - and costs pertaining to basic research incurred by an existing 
business - may be deducted in full in the year the costs are incurred. The purchase price of machinery, equipment and ships acquired for research and development purposes may be deducted in full in the year of acquisition (accelerated depreciation). Also, costs related to the acquisition of know-how, patent rights and certain license rights for use in the taxpayer's business may be deducted in full in the income year in which such costs have been incurred. In this context, the Norwegian rules that to some degree allow double deduction for research and development costs can be mentioned.

Moreover, in Denmark, in the aftermath of the financial crisis, and in order to promote growth, new machinery and equipment may temporarily be depreciated by an amount equal to 115 per cent of the purchase price (super depreciation).

Also the Swedish depreciation rules may act as an incentive for investments. In Sweden, machinery and equipment as well as intangible assets acquired from another person can generally be depreciated within a five-year period, regardless of whether the economic life of the assets is longer. In Norway, the Scheel-committee has in their mandate to review the depreciation rates.

In order to improve access to capital for small-sized enterprises, Swedish law allows a deduction for investment in shares in Swedish limited liability companies. Individuals are allowed to deduct from their income from capital an amount corresponding to half the investment amount, but there is a cap of SEK 650,000.

The Icelandic government has increased the tax burden for companies in Iceland, but some steps have also been taken to attract foreign investment and the establishment of companies. This has mainly been conducted with some sector-specific tax incentives. The increase in tax burden for companies must be seen in the light of a low Icelandic tax rate. In Iceland, some tax incentives were also adopted in order to support technology research, innovation and industry development in 2007. ${ }^{2}$ According to this scheme, companies that are engaged in R\&D projects confirmed by the Icelandic Centre for Research may deduct 20 per cent of the costs of these projects from their income tax due.

\section{Rules with purpose to protect the national tax base}

\subsection{General anti-avoidance rules}

To some degree, all of the Nordic countries have general antiavoidance rules. Even though the details of the Nordic general anti-

2 Act No 75/2007 on Government Support for Technology Research, Innovation and Industry Development. 
avoidance rules do not coincide, there are similarities. The Norwegian and Swedish general anti-avoidance rules in particular have distinct parallels while the Danish approach is somewhat different.

In Danish law pursuant to a doctrine of "substance over form", it has been argued that fictitious or artificial transactions may be set aside for tax purposes if the actual substance of the transaction conflicts with its private law form, resulting in a tax advantage. ${ }^{3}$ In this case, tax will be imposed in accordance with the actual substance of the transaction based on an overall assessment. The applicability of the doctrine of "substance over form" is limited, however, and in order for the doctrine to apply there must be an evident conflict between form and substance.

In addition to the substance over form doctrine, the doctrine of the "rightful recipient of income" plays a significant role in Danish law. The doctrine prescribes that the subject having the (legal) right to the basis of the income - e.g. a shareholding, a claim or a business activity - should also be considered the proper recipient for tax purposes of the gain/return on the shares/claim/activity. ${ }^{4}$

The Swedish Anti-Avoidance Act is applicable if the action taken by the taxpayer (or contributed to by the taxpayer) is part of a scheme that results in a material tax saving for the taxpayer, the tax saving can be assumed to have constituted the main reason for the scheme, and determining the taxable income on basis of the scheme would be contrary to the intent of the legislation. If the law is deemed applicable, the taxable income will primarily be determined as if the actions in question had not been taken, but alternative ways of determining the income also exist, which means that it can be difficult for a taxpayer to predict the outcome of application of the Anti-Avoidance Act.

The Norwegian general anti-avoidance norm is very similar to the Swedish, but court- made, not statutory. The general anti-avoidance rule is applicable if action taken by the taxpayer is mainly motivated by tax savings and contrary to the intent of the legislation. The Norwegian Supreme Court has in several cases used a high threshold to apply the general anti-avoidance rule. It is also worth noting that most cases concerning the general anti-avoidance norm are applied in domestic cases.

Finland has a long tradition of applying general anti-avoidance rules. The most recent provision in the Act on Assessment Procedure

3 The principle was originally explained by Pedersen: Skatteudnyttelse, 1989, p. 435 et seq.

4 The doctrine - it is argued - can be deduced from Sec. 4 of the State Tax Act. See Michelsen in Michelsen et al.: Lærebog om indkomstskat, 2013, p. 659 et seq. and Dam: Rette indkomstmodtager: Allokering og fiksering, 2005. 
(VML), Sec. 28, allows the Finnish tax authorities or courts to recharacterize any transaction, based on the true nature of the arrangement irrespective of its legal form. According to the provision, if a transaction has been assigned a legal form which does not correspond with its actual character and meaning, taxation should take place as if the correct form had been adopted. In addition, it must be evident that the transaction has been entered into in order to avoid Finnish tax.

In Iceland, there is a general anti-avoidance principle in the Icelandic Income Tax Act which has been interpreted by the Supreme Court to the effect that a transaction may be disregarded if its purpose is only to circumvent tax legislation.

\subsection{Specific anti-avoidance rules (SAARs) etc.}

4.2.1. CFC legislation

All the Nordic countries have CFC (controlled foreign company) rules. A Danish company is liable to tax on the income of a Danish or foreign subsidiary if the subsidiary is controlled by the affiliated group of companies, the tainted income of the subsidiary amounts to more than 50 per cent of the total taxable income and the financial assets of the subsidiary exceed 10 per cent of the total assets. The objective behind the introduction of CFC legislation was to prevent erosion of the Danish tax base caused by the increasing openness of borders to flows of capital.

The Swedish CFC rules stipulate that a resident shareholder that holds an interest in a CFC is in certain cases subject to Swedish corporate tax on its portion of the profits of the CFC entity. In other words, the foreign entity is treated as transparent for tax purposes. The Swedish CFC rules apply to direct or indirect holdings of at least 25 per cent (capital or voting rights) of low-taxed foreign companies. A foreign company is deemed to be low-taxed if the foreign tax is less than 55 per cent of the tax that would have been imposed if the foreign entity had been a Swedish limited liability company, i.e. it is deemed low-taxed if it is subject to a tax rate of less than 12.1 per cent, assuming that the taxable income according to the foreign tax legislation equals the taxable income under Swedish law.

A general exemption from Swedish CFC taxation applies to companies in countries on a special "white list", with the exception of certain businesses in some cases.

Iceland introduced CFC rules in 2009. Prior to that, no such rules were applicable in Iceland. According to the rules, if a non-resident company in a low-tax jurisdiction is owned or controlled by resident taxpayers its profits are attributed proportionately to its resident shareholders and taxed according to the Icelandic income tax rate. 
This is the case regardless of whether the profits have been distributed or not.

According to the Icelandic CFC rules, the term "low-tax jurisdiction" is defined as a country where the general income tax rate on corporate profits is less than two thirds of the Icelandic rate that would apply if the company was resident in Iceland.

The Icelandic CFC rules are not applicable if one of the following conditions is met: First, if the company is resident in a treaty country (outside the EEA, Switzerland and the Faroe Islands) and its income is not mainly financial income. Second, if the company is resident in an EEA state, Switzerland or the Faroe Islands and is engaged in genuine business activities in that country and the Icelandic tax authorities can request all necessary information according to an international treaty.

The Norwegian tax act has rules for taxation of Norwegian controlled companies that are resident in a low-tax jurisdiction. Basically, a company is considered to be Norwegian controlled if half of the company is directly or indirectly owned by Norwegian taxpayers. A country is considered to be a low-tax country if the corporate tax is lower than $2 / 3$ of the equivalent Norwegian company tax. The Norwegian CFC rules are not applicable if the investment in the CFC company is of a passive nature or if the company is engaged in genuine business in the low-tax country.

Finnish CFC rules may apply if one or more Finnish residents control a foreign corporate entity registered in a low-tax state. According to VYL, a resident shareholder with a share in a controlled foreign company is liable to pay tax on his share of the CFC's income if certain conditions are met. Because of the change in corporate tax rate in Finland in 2014, the CFC conditions can now only apply to countries with an actual rate of income tax for CFC less than 12 per cent ( $3 / 5$ of the tax rate of a corporate body resident in Finland).

\subsubsection{Exit taxation}

All the Nordic countries have exit taxation, but the design of this is somewhat different. In Denmark, exit tax is triggered if a company ceases to be fully liable to tax in Denmark, or if a resident company becomes resident in another state according to a tax treaty, the company should be considered as having disposed all assets and liabilities that no longer are subject to Danish taxation. The assets and liabilities should be considered sold at fair market value at the time of emigration. Likewise, the transfer of assets and liabilities within a company to a foreign permanent establishment or a foreign head quarter, with the result that the assets and liabilities are no longer subject to Danish taxation, is treated as a sale at fair market value at the time of the transfer. 
In Swedish law, exit taxation is triggered when an asset is no longer subject to Swedish corporate tax. This may for instance be the case when Sweden enters into a new double tax treaty, when an asset is transferred from Sweden to another country or when the owner of an asset changes his state of residence for treaty purposes from Sweden to another state, if this means that Sweden's taxing right ceases, either according to Swedish domestic law or because the relevant double tax treaty precludes Sweden from taxing income relating to the asset. In such case, the taxable income of the owner shall be computed as if the asset had been sold at market value.

In Finnish law, exit taxation is triggered if a foreign company sells its business property which belongs to its Finnish permanent establishment (PE), the realized capital gains are included in the taxable profits of the PE in Finland. The taxable amount realized by the sale is calculated by deducting the book value from the current value. The tax treatment will be the same according to the amendment mentioned, if the Finnish permanent establishment is closed down and its business property is transferred to another part of the company in another country. Also transferring a part of the business property of the Finnish PE to another part of the company elsewhere without closing down the Finnish PE will lead to a similar taxation of the transferred property.

In Norwegian law, it is possible to transfer the ownership of an object to foreign owners without triggering tax. As a main rule, tax is triggered when objects are transferred out of Norwegian jurisdiction. This exit rule is supplemented by some special rules. When exit tax is triggered deductions are only given to tax subjects resident in Norway or the EU. The tax subjects may be given a tax credit, but interest will accrue.

The issue of exit taxation has been on the agenda in Iceland for the past few years and the focus has been on exit taxation of cross-border mergers. The rules on taxation of cross-border mergers were amended in 2013 but before that time, domestic mergers could benefit from a tax exemption while cross-border mergers were subject to exit taxation at the time of relocation of the merging company.

In December 2013, the EFTA Court considered the Icelandic rules on mergers to be in breach of the provisions in the EEA Agreement on freedom of establishment and free movement of capital. Iceland has now amended its legislation as regards the taxation of cross-border mergers. The new rules, applicable as of 1 January 2014, imply that companies that intend to merge cross-border (within the EEA) can choose between two options: Either they can pay tax on unrealized capital gains relating to assets and shares that accrued while the company was established in Iceland or they can decide to postpone the tax 
payment. A deferral of the tax payment can only be granted for up to five years irrespective of whether the assets have been realized or not at that time.

\subsubsection{Transfer pricing}

All the countries reporting seem to have challenges concerning transfer pricing, particularly concerning pricing and documentation. These challenges are solved in somewhat different ways. The current Danish regime sets forth the arm's length principle, which should be interpreted in line with Art. 9(1) of the OECD Model and the OECD Transfer Pricing Guidelines. ${ }^{5}$ The transfer pricing rules apply to "controlled transactions" and cover cross-border transactions as well as domestic transactions.

In Danish law, transfer pricing information and documentation requirements apply. Accordingly, when filing the tax return the tax authorities should be informed about the nature and scope of the controlled transactions. In addition, the taxpayer is obliged to prepare and retain written transfer pricing documentation. On request, the transfer pricing documentation must be submitted to the Danish tax authorities.

Swedish law stipulates that if the income of a Swedish enterprise, due to the fact that the enterprise has entered in an agreement with another enterprise on other than arm's length terms, is lower than would otherwise be the case, then the income shall be computed as if those terms did not exist, provided that the contracting party is not liable to tax in Sweden, that it can be assumed that the enterprises are associated, and that it does not follow from the circumstances of the case that the terms have been agreed on due to other reasons than the fact that the enterprises are associated.

The Swedish legislator has focused on documentation requirements in recent years. A number of transfer pricing disputes have been decided by courts in the last few years. Many of them have concerned deduction of interest by Swedish enterprises in private equity fund structures and in particular the question of whether the interest rates on shareholder loans to Swedish enterprises have exceeded the arm's length rate.

In Finish law, a transaction between a taxpayer and a related party where these parties have agreed on terms or imposed terms which differ from those which would have been agreed upon between independent parties, and for this reason the taxpayer's business profits or income from other activity remain smaller or the taxpayer's loss be-

5 See Wittendorff: Armslængdeprincippet i dansk og international skatteret (2009), p. 262 et seq. 
comes bigger than it would otherwise have been, the income is increased by the amount that would have been accrued when the terms had corresponded to what would have been agreed between independent parties. This principle also applies to transactions between an enterprise and its permanent establishment. Provisions include the amendments of the situations when parties to a transaction are related in a way that a party has control of another party.

In Finish law, the written documentation on annual transactions with related parties with some limitations must contain the following information: 1. Description of the business. 2. Description of all associated relationships. 3. Information on transactions between associated parties and between an enterprise and its permanent establishment. 4. Functional analysis of all transactions. 5. Comparability analysis including the available information on points of comparison. 6 . Description of the transfer pricing method and its application.

In 2012, all nationwide transfer pricing tasks in Finland were centralized to a three-year Transfer Pricing Program, which is located in the Large Taxpayers' Office.

In Iceland, statutory rules on transfer pricing entered into force at the end of 2013, but until that time no specific rules on transfer pricing with general applicability were applicable in Iceland apart from the general anti-avoidance principle. However, there were some statutory rules on transfer pricing in specialized tax legislation.

In Norwegian statutory law, transactions where income is reduced because of mutual interest may result in an increase of the taxpayer's income. Income will be determined as if there had not been mutual interest. OECD guidelines are used both for domestic and international transactions between related parties. From 2008, taxpayers are obliged to prepare and retain written transfer pricing documentation.

\subsubsection{Limitations on deductibility of financing expenses}

In Denmark, the deductibility of financing expenses may in general be restricted under three sets of rules for corporate taxpayers. All three rules apply domestically as well as cross-border.

1. The thin capitalization test; a company is thinly capitalized if the debt-to-equity ratio exceeds $4: 1$, provided that the controlled debt exceeds DKK 10 million. If a company is considered thinly capitalized, interest expenses and capital losses, on the part of the controlled debt that should have been converted to equity to avoid the limitation, are not deductible. However, if the company is able to substantiate that similar financing could have been obtained without security from other group companies, the 
company will be allowed to deduct interest expenses even though the $4: 1$ ratio is exceeded.

2. The asset test; net financing expenses may be deducted only to the extent the expenses do not exceed a standard rate of presently 4.2 per cent (2014) of the tax base of certain qualifying assets.

3. The EBIT test; net financing expenses may not exceed 80 per cent of earnings before interest and tax. Both the asset test and the EBIT test only apply to net financing expenses exceeding DKK 21.3 million (2014). The two limitations apply to all kinds of debt - not only controlled debt.

Until 2009 Swedish tax legislation did not provide for any limitations to the deduction of interest expense as long as the interest rate was determined on an arm's length basis. Furthermore, the interest deduction limitations were given a significantly wider scope in January 2013 when the legislation was once again amended. The previous interest deduction limitations targeted loans between associated enterprises relating to the financing of an intra-group acquisition of shares. The new limitations apply to any loans between associated enterprises. Furthermore, the previously applicable "safe haven" which allowed deduction of interest when the beneficial owner of the interest income was subject to at least 10 per cent tax, has been modified so that deduction, under certain circumstances, can be denied even if the 10 per cent condition is fulfilled.

Under the new interest deduction limitation rules, interest expense on loans between associated enterprises is as a main rule nondeductible unless the person who is actually entitled to the income is subject to at least 10 per cent tax. According to the preparatory works, the phrase "actually entitled to the income" shall correspond to the expression "beneficial owner". Furthermore, even if the beneficial owner is subject to 10 per cent tax or more, deduction may be denied if the main reason for the loan is to gain a substantial tax benefit.

The 10 per cent requirement looks at the tax that would have applied if the interest income were the only income of the beneficial owner of the interest. Other income and losses from the operations of the beneficial owner are disregarded. However, if deductions can be made which would not have been available in Sweden, for instance basic allowances or notional interest deduction, that is taken into account for the purpose of determining the tax rate that applies to the interest income.

Moreover, regardless of the 10 per cent requirement, interest may be deducted if the beneficial owner of the interest is resident in the European Economic Area or in a state with which Sweden has entered into a comprehensive double tax treaty, provided that the borrower 
can prove that the loan is essentially motivated on commercial grounds. For the purpose of determining whether there are sufficient commercial grounds for the loan, the rules state that it should be taken into account whether the financing could have been made in the form of a contribution instead of a loan.

The rules also contain several anti-avoidance provisions. For instance, interest on back-to-back loans via an external party may be non-deductible even though such interest does not fall within the scope of the main rule, as the external party is not an associated enterprise.

In Finland, the thin capitalization rules have been mentioned in some working group memorandums and government proposals. The Ministry of Finance did not take action and present a proposal to make thin capitalization rules part of the Finnish tax system. Instead, provisions on interest deduction limitation were added to the Finnish tax system. The right of corporate bodies, general partnerships and limited partnerships to deduct interest expenses is limited in business taxation from the beginning of 2014. Interest expenses can be deducted in full to a sum equivalent to interest income. Where net interest expenses, meaning interest expenses that exceed interest income, are no more than $€ 500,000$, they can be deducted in full. Interest expenses exceeding $€ 500,000$ are tax deductible to the amount corresponding to at most 25 per cent of the business income tax result. Net interest expenses exceeding the 25 per cent amount are non-tax deductible. However, the sum of non-tax deductible interest expenses based on the 25 per cent limit is at the most an amount corresponding to intragroup net interest expenses.

Interest deduction limitation rules do not apply to credit institutions or insurance and welfare institutions or, to a certain extent, to their affiliated bodies. Non-tax deductible net interest expenses can be deducted from taxable income of successive fiscal years within the yearly limits of tax-deductible interest expenses.

There are no statutory thin capitalization rules in force in Iceland. A working group submitted a report on the issue in June 2012, with suggestions on how to formulate new thin capitalization rules.

I Norway, the arm's length principle is used to reclassify thin capitalization. From 2014, the government introduced a new set of rules that intercept interest deduction. Simplified, the new rules intercept interest deductions between related parties when the interest is higher than 30 per cent of earnings before interest, tax and depreciation/amortization (EBITDA). To prevent avoidance of the rules for loans between unrelated parties is in some cases included. An important example of this is back-to-back loans. There is a threshold 
amount, and interest deductions are intercepted only when interests exceed NOK 5 million.

\subsubsection{Hybrid entities and hybrid financial}

Hybrid entities present difficult challenges for most countries and may result in both double taxation and double non-taxation. The Danish rules are particularly interesting. Denmark has introduced provisions on hybrid as well as reverse hybrid entities, which entail that the domestic tax treatment in some situations depends on the tax treatment in other jurisdictions. Both provisions could be seen as a reaction to tax planning based on the US check-the-box rules. Accordingly, if a company or association should be treated as a transparent entity according to the tax rules of a foreign state, with the effect that the company's income should be included in the income of an affiliated company in this foreign state, the company should - if certain conditions apply - be reclassified as a transparent entity for Danish tax purposes. The objective of the provision is to mitigate the possibility of "creating" deductible interest expenses in Denmark in situations where the foreign recipient is exempt from tax on the interest on payments, as the interest payments should be considered internal transfers within the same entity pursuant to the tax rules in the foreign state.

Conversely, certain tax transparent entities should be reclassified as separate taxable entities if more than 50 per cent of the shares or voting rights are held directly by foreign investors and the tax domicile of such foreign investors is in a country in which the Danish entity is treated as a taxable entity or in a non-EU Member State which does not have a tax treaty with Denmark. Here the aim is to prevent tax payers from exploiting different entity qualifications to "create" double non-taxation.

Cross-border tax arbitrage by using hybrid financial instruments has been curbed inbound and outbound. Accordingly, if a company or association etc. is indebted or similarly obligated to an individual or company resident in another country and the claim according to foreign tax rules is considered paid in capital, the debt shall also be regarded as equity with respect to the Danish tax computation. The objective of this provision is to abolish the potential asymmetrical tax treatment of certain hybrid financial instruments.

In addition, the applicability of the inbound dividend participation exemption has been limited to situations where the foreign paying company is not allowed under the tax laws of the country of its residence to deduct the payments, which are considered dividends under Danish tax law. The purpose of the provision is to prevent Danish companies from receiving tax exempt dividends in situations where the foreign paying company can deduct the payment. 


\subsubsection{Exchange of information}

Tax rules cannot be effective without information. In a world with higher degree of cross border integration, information is increasingly important.

In recent years, Sweden has entered into information exchange agreements with a number of low-tax jurisdictions. Furthermore, information exchange clauses have been included in double tax treaties with several states known for bank secrecy, most notably in the double tax treaty with Switzerland.

The discussion in Sweden so far has mainly focused on the exchange of information relating to individuals, and the increased pressure on individuals to freely provide information to the Swedish Tax Agency in order to avoid prosecution and tax surcharges created by the new means of obtaining information from tax authorities in other states. The relevance for protecting the Swedish corporate tax base from the increased opportunities of exchanging information remains to be seen.

Like all the Nordic countries, Finland has a longstanding involvement in international exchange of information in tax matters. According to the OECD Global Forum of Transparency and Exchange of Information for Tax Purposes - Peer Review Report (28 February 2013), Finland was able to exchange information in tax matters through a broad network of EOI arrangements covering 119 jurisdictions. Finland was also one of the first countries to sign and ratify the Multilateral Convention and the 2010 protocol which came into force in 2011.

Since 2011, Norway has entered into approximately 40 information exchange agreements, mainly with tax havens. Exchange of information takes place upon request. It remains to be seen how effective the agreements will be. Additionally, the regular tax agreements have provisions regarding exchange of information in accordance with the OECD model convention.

\section{Particular challenges}

It is challenging to protect the national tax base and still be in line with EU law. EU law and the national tax base can be considered opposing forces.

For example, whether the Danish specific anti-avoidance provisions should be considered in line with EU law has been subject to considerable debate over the years. A common "reaction" to the EU law challenge has been to expand the scope of the anti-avoidance provisions. For example, both the thin capitalization rules and the CFC rules now apply domestically as well. However, despite this it has still 
been questioned whether these rules in effect have been brought in line with EU law.

In addition to the discussions on thin capitalization and CFC rules, the EU law compatibility of other anti-avoidance provisions has been debated as well. Thus, elements of anti-avoidance rules such as the asset and EBIT test, the rules on hybrid financial instruments, and the rules on exit taxation are still subject to criticism in the literature from an EU law standpoint. Moreover, it has been discussed whether the tax consolidation regime is in line with EU law.

Most countries also have challenges relating to the beneficial owner of dividends. The Swedish approach is particularly interesting. Swedish double tax treaties conform to the OECD model in most respects and consequently typically require that the beneficial owner of outbound dividends, interest and royalty is a resident of the other state in order for the limitations on Sweden's taxation rights as a source state to apply. However, the beneficial owner concept is unknown in the Swedish legal system and very few cases dealing with that concept have been decided.

Furthermore, in Sweden the beneficial owner requirement of tax treaties is likely to play a less prominent role than in many other states. This is due to the fact that Sweden does not impose tax on interest paid to non-resident lenders and that exemptions from withholding tax on dividends typically apply under Swedish domestic legislation when dividends are paid to a foreign company, regardless of whether that company is the beneficial owner of the dividends. Moreover, in regard to royalty paid to non-resident taxpayers, Sweden does not impose a withholding tax on the gross amount. Instead, the non-resident taxpayer is taxed as if the payments were attributable to a permanent establishment in Sweden. This means that the nonresident taxpayer is taxed on its net income, i.e. the royalty income is regarded as income attributable to a permanent establishment and expenses connected with the income are deductible. Under for instance a back-to-back structure only a profit margin determined according to the arm's length principle would be taxable in Sweden as outgoing royalty payments are in principle deductible. In other words, pursuant to Swedish domestic law there is less need for relying on tax treaty benefits in respect of dividends, interest and royalty than in many other states, meaning that there is less need to determine whether the beneficial owner of the income is a resident of a contracting state.

Compared to the other Nordic countries, Finland has set its formal tax rate a little below the average. From a tax competition point of view, however, the Estonian system and tax rate in corporate taxation can be seen as tempting compared to the Finnish rate. A look at the 
Nordic countries may therefore give the wrong picture. The real challenges are not in but outside of Scandinavia.

\section{Corporate income tax rates and revenues}

The corporate income tax rates (CIT-rates) have decreased steadily throughout the OECD area the last 20-30 years. Figure 2 shows the development of corporate tax rates in OECD and in the Nordic countries since 1988. The reduction in CIT-rates in the Nordic countries due to the comprehensive tax reforms in the beginning of the nineties is clearly visible in the figure. The CIT-rates in Norway, Sweden and Finland have been more or less stable after the reforms, while the rate in Denmark has followed the OECD average quite closely. All the Nordic countries except Iceland have recently reduced the CIT-rates, and Denmark has announced further reductions down to 22 per cent in 2016 according to the "Growth Plan DK". This reform in Denmark is not financed by broadening the corporate tax base, but through a reduction of public spending. The argument for this is primarily to stimulate growth and investments, but it is also interesting that the Danish report mention that the potential for further base broadening is limited due to earlier base broadening reforms. In Iceland the CITrate dropped substantially in 2001 from 30 per cent to 18 per cent. In the wake of the financial crisis in Iceland in 2008 the corporate (and capital) income tax rates increased. 


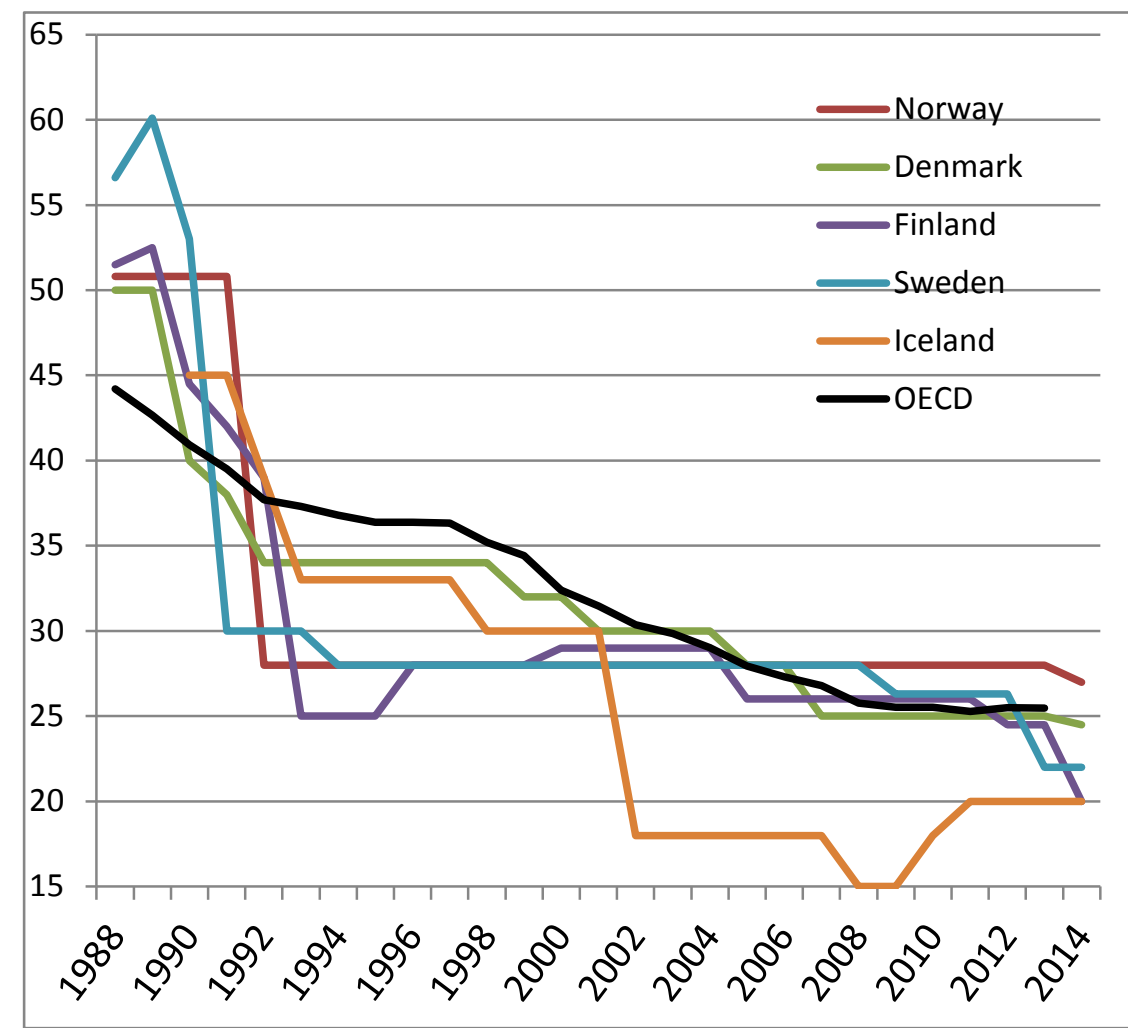

Figure 2: Corporate income tax rates. OECD average (unweighted) and the Nordic countries. 1988-2014

Source: National Reports and OECD 


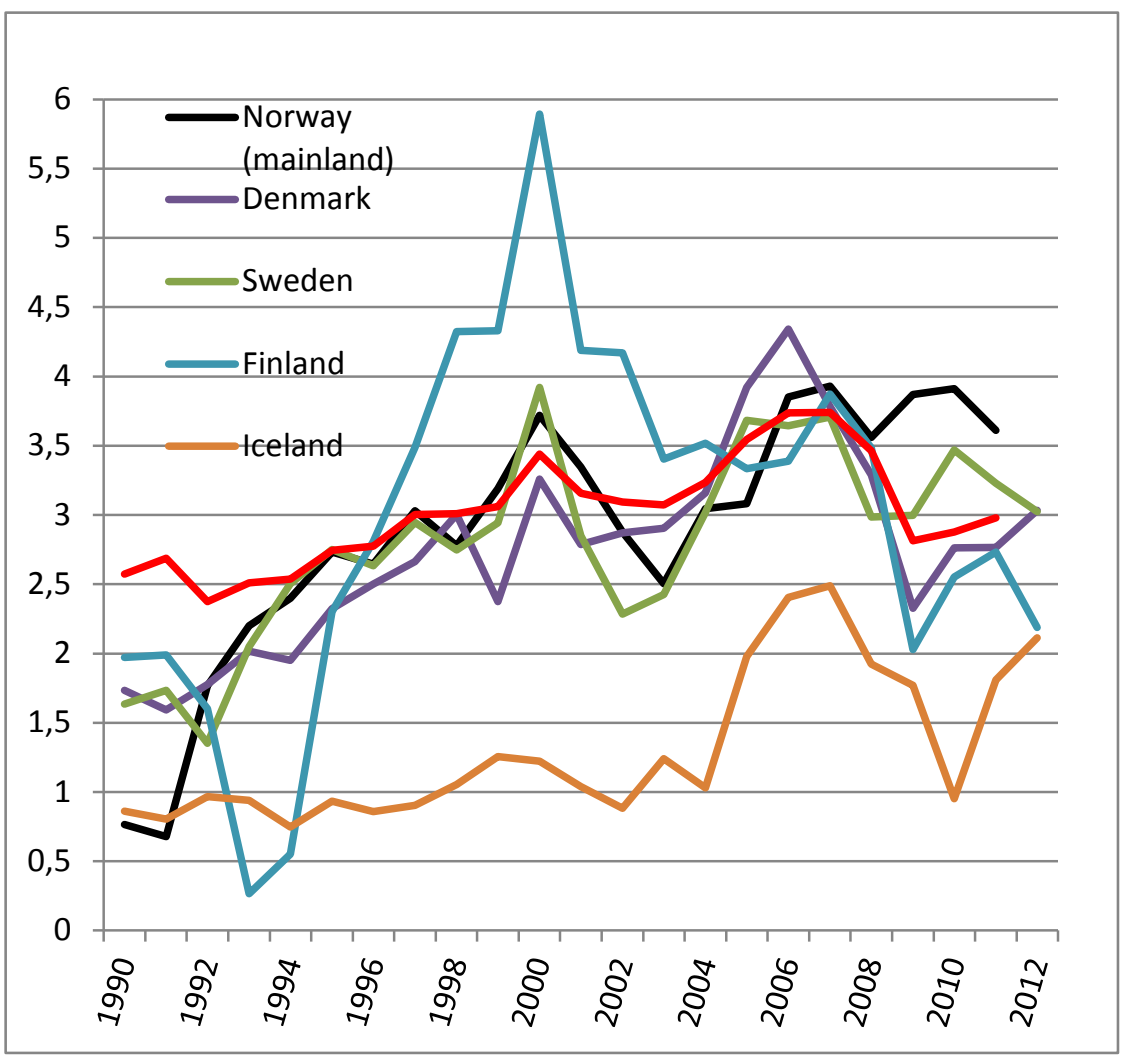

Figure 3: Corporate tax revenues as a share of GDP. OECD average (unweighted) and the Nordic countries. 1990-2012

Source: National Reports and OECD

Figure 3 shows corporate tax revenues as a share of GDP for OECD and for the Nordic countries. The data for Norway shows mainland corporate tax revenues as a share of mainland GDP, excluding the petroleum industry.

Considering the reduction of statutory CIT-rates, the tax revenues from corporations have been remarkably stable. Not even the drop in the CIT-rate from 30 per cent to 18 per cent in Iceland in 2002 had a significant impact on the tax revenues (rather the opposite considering the tremendous growth in tax revenues between 2004 the economic collapse in 2008). From 1990 to the financial crisis in 2008, all countries experienced a steady increase in corporate tax revenues (Finland peaked in 2000 though). The most plausible explanation for this is that tax rate reductions have been accompanied by tax base broadening to finance the reforms. Bringing taxable profits closer to real profits increases the share of tax revenues to GDP. 
Tax-cut-cum-base-broadening types of reforms are also likely to improve resource allocation, as the efficiency of the tax system improves and thereby further strengthening the tax base. There is reason to believe that at least some of the increase in corporate tax revenues in the Nordic countries during the nineties is due to a considerable improvement of resource allocation, as indicated in the Norwegian and the Danish national report.

Another explanation is that the share of global profits earned by incorporated businesses have increased relative to the non-corporate sector, due to income shifting between the corporate and noncorporate sector motivated by reduced corporate income tax rates (Sørensen 2007). However, the corporate tax revenues have not increased since 2000, except from in Iceland. The "dot com" crisis in 2000 and the financial crisis in 2008 led to a fall in corporate tax revenues for most countries, and the corporate tax revenues as a share of GDP in 2012 are at 2000 level or below for all Nordic countries and OECD (again except from in Iceland).

\section{Taxing capital and corporate income in an open econo- my}

One of the most fundamental results in the tax economy literature is the Diamond and Mirrlees theorem from the beginning of the 1970s. Normally it is preferable to have many small tax wedges widely spread in the economy, because the deadweight loss from taxation increases more than proportional with the tax rate. However, according to the Diamond and Mirrlees theorem, it cannot be optimal to have distortionary taxation of production factors (Diamond and Mirrlees 1971). Distortionary taxation should be concentrated entirely upon the consumer side and leave the production sector undistorted. This result depends on the condition that all pure profit can be taxed and that the tax and transfer system can be used to distribute welfare among consumers. This result is derived in a closed economy setting, and is thus not a consequence of capital mobility. However, the result also holds in an open economy if all income is taxed according to the residence principle. This means that it cannot be optimal with source taxation of corporate income, except from (country specific) pure profit.

All OECD-countries have corporate taxes, despite the Diamond and Mirrlees theorem. There are a number of reasons for this. The most obvious reason is that the Diamond and Mirrlees model is quite stylistic and that the critical conditions are not fully satisfied. Another reason is that source based corporate income tax is partly paid by for- 
eigners. This is possible because most countries have tax crediting schemes for foreign paid corporate taxes in their tax treaties. The burden of the foreign tax therefore rarely falls on the investor. It is also a common argument that some level of corporate income tax is useful because it serves as a backstop to the personal income taxation. Zero taxation of corporate income could also create motives for income shifting between different organizational forms and different types of income.

Despite the arguments above, it is no doubt that a higher degree of capital mobility is an important reason for the low-rate-cum-broadbase reforms we have seen the last two-three decades. The possible efficiency loss from a source based corporate tax and (at least elements of) tax competition makes it costly to have a high statutory corporate tax rate. However, it is not necessarily the case that we are witnessing a "race to the bottom" due to tax competition. Although the tax competition literature predicts inefficiently low tax levels as a result of competition between independent governments over mobile production factors (see box 1 for an introduction to the tax competition theory), the concept of tax competition is not at all a straightforward phenomenon.

Firms decisions about where to invest, how much to invest and where to move taxable profits are influenced by a range of factors, whereas taxation is one. Investment decisions are influenced by effective tax rates. Effective tax rates take into account the tax rules for calculating taxable profits, such as depreciation rules and other characteristics of the tax base. When firms decide where to invest or establish the business they take average effective tax rates into account. Given the location decision, the firm has to decide how much to invest at the margin. In this case the marginal effective tax rate is the relevant tax rate. Multinational enterprises can use transfer pricing, thin capitalization or other techniques to move profits to low tax countries, so called profit shifting. The relevant tax parameter for this decision is the statutory tax rate. States can engage in tax competition along all these dimensions. 


\section{Box 1: The basic tax competition model}

The concept of tax competition has been a part of the tax literature since Tiebout's theory of "voting with your feet" in 1956, but it was not until the mid-1980s that economists really started to formalize tax competition models. The basic tax competition model can be attributed to Zodrow and Mieszkowski (1986) and Wilson (1986). In the simplest version of the model, firms produce a single output using perfectly mobile capital and immobile labor. The output is sold to residents as a consumption good (C) and to governments as an intermediate good, which is then transformed into a public good (G). The amount of capital in the world economy is fixed and governments finance the public good by taxing the capital employed within its borders.

The Government in each state maximizes the social utility function $U(C, G)$ subject to the budget constraint $t C(m c)=G$. Capital demand is a function of the marginal cost of capital mc, which is the sum of after tax return on capital $r$ and the tax rate $t$, so that $m c=r$ $+t$. Taxes are set according to the optimality condition $d G=d t \cdot C+$ $t \cdot d C$. The optimal tax rate $t^{*}$ is the $t$ that equates the marginal utility of $G(d G)$ and the marginal tax cost, which is the sum of the marginal cost of capital $d t \cdot C$ and the marginal cost related to capital outflow due to a tax increase $t \cdot d C$.

In a closed economy $\mathrm{dC}=0$, and the optimal tax rate is set according to the well known Samuelson rule $d G=d t \cdot C$, where the marginal utility of a tax increase equals the marginal cost of collecting the tax, which in this case is the marginal cost of capital. In an open economy an increase in the tax rate will lead to an outflow of capital $\mathrm{dC} / \mathrm{dt}<0$, which imply an additional cost of taxation $t \cdot d C$ (the second term of the optimality condition). This effect reduce the welfare effect of a given tax increase and leads to suboptimal levels of $G$ and $t$. In other words; the marginal cost of taxation is higher in an open economy setting with capital mobility. Since the after tax return on capital $r$ is fixed (at least from a small countries view) must the increased cost of capital $(d t \cdot C)$ and the additional cost due to capital outflow $(t \cdot d C)$ be financed by a reduction in return of immobile labor input, which means a reduction of wages.

The optimal strategy from a national point of view is still to choose a lower tax rate than $t^{*}$ and thus a suboptimal provision of the public good. This is due to the negative external effect of reducing the tax rate in a global perspective. The cost of reducing the tax rate $t \cdot d C$ is passed on to other countries as the tax reducing country attracts capital on other countries expense. This leads to a suboptimal tax level worldwide and a global welfare loss due to the under provision of the public good. 
In the basic model governments can only tax capital to finance the public good. In a more realistic setting, governments can also tax wages. If labor is both immobile and the supply of labor is fixed, a tax on labor income would always be superior to a tax on capital, and optimal capital taxation is zero. A tax on capital will lead to capital outflow and a reduction in labor productivity until the reduction in wages equals (and finance) the tax. Since the tax is financed by a reduction in wages, it would be better to tax labor income directly. However, even if the taxation of wages distorts leisure-labor decisions revenue need should be met by taxing labor income only, at least for small open economies (Bucovetsky and Wilson (1991)).

\section{The Nordic countries and tax competition}

\subsection{Statutory tax rates and profit shifting}

Figure 2 shows the statutory corporate income tax rates for the Nordic countries and the OECD. As stated above, the statutory tax rate is the relevant tax parameter for profit shifting. The statutory tax rates vary from 20 per cent in Iceland to 27 per cent in Norway.

Norway is the only Nordic country with a higher CIT-rate than the OECD average. The question is if we need to worry about the statutory tax rates in the Nordic countries in a tax competition perspective?

When reading about profit shifting in the mass media, one could easily get the impression that profit shifting in multinational firms is costless and easy. This is not necessarily the case. Most countries have a quite comprehensive set of anti-avoidance rules (see chapter 4) and most firms are eager to apply to those rules. However, profit shifting do occur. The Danish national report states that 56 per cent of Danish MNEs did not pay any corporate income tax in 2012. The Norwegian national report refers to several studies which indicate that the taxable profits of multinational enterprises in Norway are significantly lower than for domestic firms. One study shows that as much as 30 per cent of the potential corporate tax revenue is lost due to profit shifting (Tropina et. al. 2010).

When a firm moves profit out of a high tax country it doesn't make sense to move it to another high tax country with a slightly lower tax rate. Profit shifting means shifting profits from high tax countries to low tax countries or tax havens. So even if (some of) the Nordic countries have slightly higher tax rates than "comparable" countries in the OECD-area, it would be virtually impossible to compete with low or no tax jurisdictions over profits, unless the statutory tax rate is reduced to a mere minimum. However, the Danish report claims that 
the effect on the tax base of reducing the CIT-rate is quite large, and that reduced profit shifting accounts for a fair share of this effect.

\subsection{Effective tax rates and investments decisions}

The relevant tax parameters for investments decisions are effective, not nominal tax rates. Figure 4 shows effective average tax rates (EATR) for EU-countries and Norway for 2012. The EATR in figure 4 are produced by ZEW for the EU commission (EU commission 2012) and are calculated as the average tax burden on a hypothetical investment equally allocated to five assets (machinery, intangibles, inventory, industrial buildings and financial assets). The hypothetical investment is financed by 55 per cent retained earnings, 10 per cent new equity and 35 per cent debt. The market interest rate is assumed to be 5 per cent and the inflation rate is 2 per cent. The profit rate when calculating the average tax rates is 20 per cent.

The EATR is the relevant tax rate when firms decide where to invest or localize business. Figure 4 shows that most Nordic countries are slightly below the EU average, except Norway, which is close to 6 per centage points above the EU average. Even though 6 per centage points can be considered to be significant, it does not necessarily have a big impact on localization decisions. The reason is that localization decisions are influenced by a range of other factors, which are probably more important than taxes. The Nordic countries are for instance characterized by a high-skilled work force, although labor costs are quite high. Another important factor with a great impact on localization decisions are various obstacles for doing business for instance due to a high level of bureaucracy in public service. The public administrations in the Nordic countries are known to be "business friendly" and it is relatively easy to establish and run a business.

Andersen et al. (2007) concludes in a report about the Nordic Model that the Nordic countries offers a good business climate with high technological levels, well-functioning financial markets, good systems for corporate governance and low compliance costs. The Norwegian national report also makes references to several studies that support this impression. ${ }^{6}$ The impact of a high tax burden on the localization decision is probably (at least to some extent) compensated for by a good business climate. This is especially the case when the Nordic countries are compared to the countries to the right of figure 4 . It is probably not a good idea to engage in competition over the localization of businesses and investments with Bulgaria, Cyprus and Romania by substantially lowering the effective average tax rate.

6 The Global Competitiveness Report 2013-2014 (World Economic Forum) and Doing Business 2014 (The World Bank). 
Figure 5 shows effective marginal tax rates (EMTR) for OECD countries for 2012. The calculations of EMTR are based on the same assumptions as EATR, but the net profit is zero

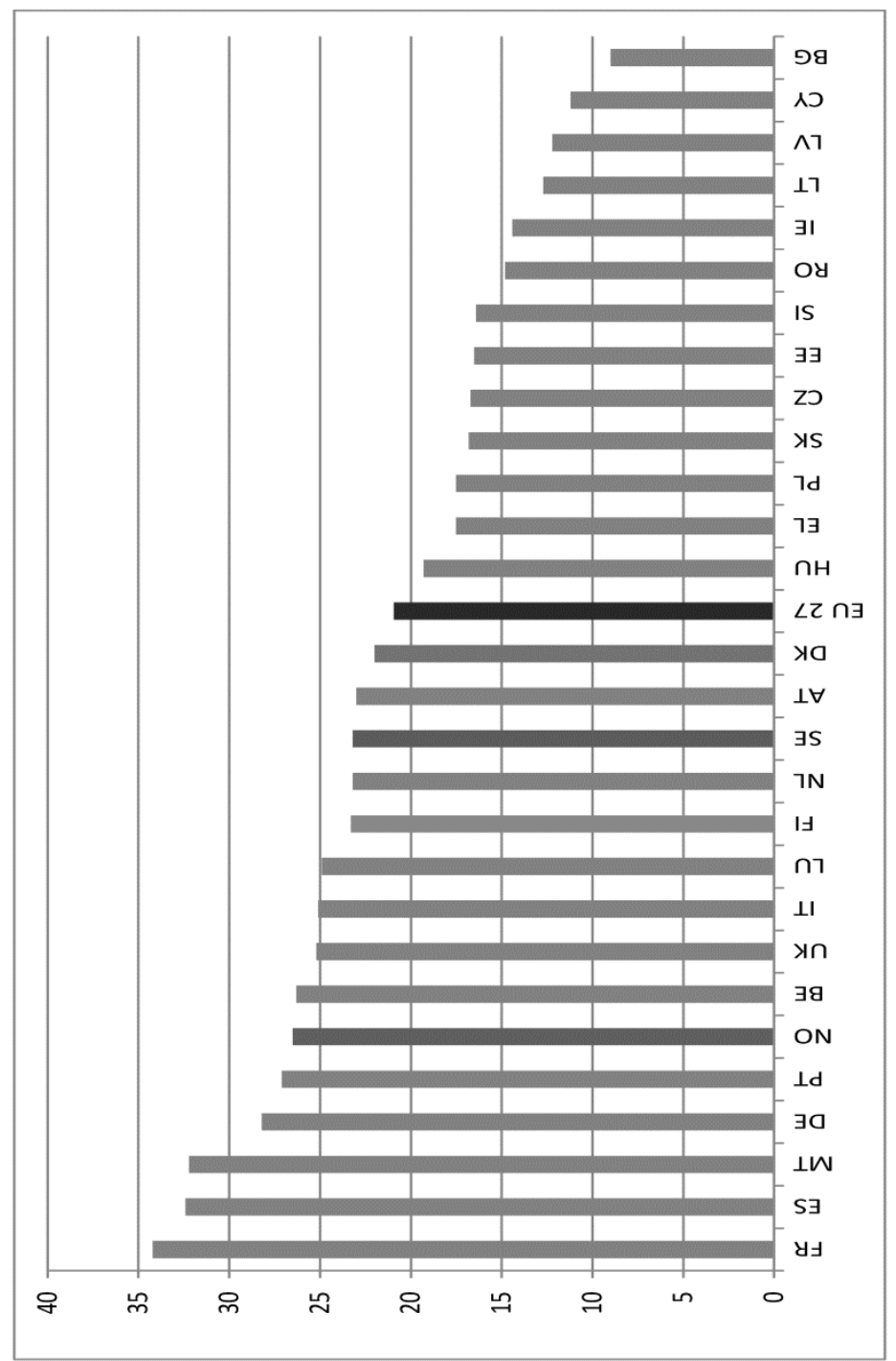

Figure 4: Effective average tax rates on corporate income. EU and Norway. 2012

Source: Spengel et al. (2012) 


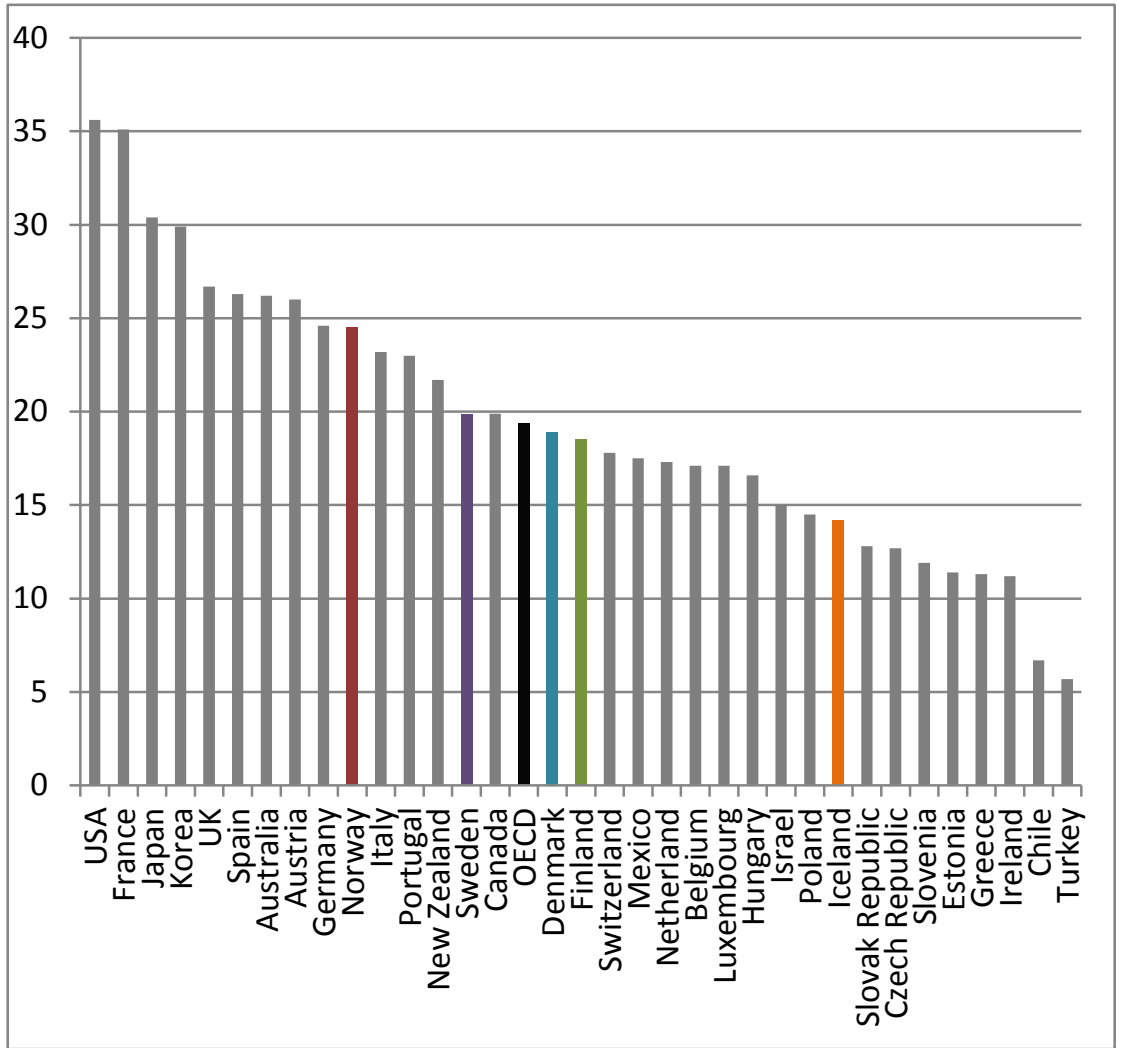

Figure 5: Effective marginal tax rates on corporate income. OECD. 2012

Source: Chen and Mintz (2012)

by definition (i.e. it just equals the required rate of return). Again we find Sweden, Denmark and Finland close to the (OECD) average at 19,4 per cent. Norway is almost 5 per centage points above the OECD average and Iceland is quite low with 14,2 per cent. It is reasonable to believe that the EMTR has a greater impact on the investment decision than the average tax rate. The reason is that the localization decision is already taken and the investor or the firm can take most of the factors mentioned above that are relevant for the localization decision as given. Hence the impact of the tax rate on the investment decision at the intensive margin (i.e. how much to invest) is relatively bigger. This could especially be the case if a multinational is established in countries which are comparable in terms of business environment and maybe also geographically close to each other. It also seems that larger economies like for instance the US, France, UK and Germany, can allow themselves to have higher effective tax rates than smaller economies. 
Based on this simple analysis of statutory and effective tax rates it seems to be a weak case for the Nordic countries to engage in tax competition over profits or localization of businesses, by lowering the statutory or EATR. ${ }^{7}$ A possible exception could be Norway, which is ranked at the top of the Nordic countries. On the other hand, it seems from the Norwegian national report that reducing the tax rate is considered to be an inadequate response to prevent profit shifting, for the same reason mentioned above. It then seems to be a stronger case for stimulating investments at the intensive margin by lowering the effective marginal tax rates.

The obvious strategy for lowering EMTR (contrary to EATR) is to broaden the tax base and lowering the statutory tax rates. Special deductions or tax credits to attract foreign direct investments will reduce EATR, but not (necessarily) the EMTR, because it does not make room for rate reductions. The same argument goes for investments incentives through increased depreciation rates or "investments windows" (Denmark) and "start-up depreciations" (Norway). Thus the low rate - broad base approach still seems to be the optimal tax strategy for the Nordic countries, also when it comes to attract investments.

\section{Capital structure - distortions and thin capitalization}

A common feature of all the Nordic corporate tax systems is the asymmetric treatment of debt and equity financed investments. While nominal interests are deductible in taxable income (with some exemptions), the capital cost (i.e. the normal return) of equity is not. This is the standard corporate income tax model applied in most countries. Figure 6 shows the effective marginal tax rates of investments entirely financed by new equity or debt respectively. The different tax treatment of debt and equity obviously produces huge differences in effective marginal tax rates. As explained in the Norwegian national report, this was not considered to be very problematic when the current tax system was introduced in 1992. The reason was that this asymmetry was "reversed" at the personal tax level, where interests where taxable as capital income and dividends was not. Thus the personal investor would face the same total tax rate, irrespective of the choice of

7 It is relevant to point out that these conclusions are more modest than what seems to be the case in Denmark. The Danish national report emphasize that "the level of investments is highly sensitive to the taxation of capital ..." and that "Even a minor worsening of the after-tax-returns can lead to capital being invested abroad instead of in Denmark or profit being shifted to other countries ...". 
finance, as is shown in figure 7 where effective marginal tax rates are calculated for the corporation and the personal shareholder combined. In Norway and Finland this was considered to be perfectly neutral because the capital and corporate income tax rate was the same. This neutrality still holds for Norway in 2012. This was not entirely the case in all Nordic countries, but in general at least some of the asymmetry was compensated for at the personal level.

However, this relies on the assumption that the corporate and personal taxation is fully integrated. In an open economy with a high degree of capital mobility, this is not the case. With international integrated financial markets the marginal investor could as well be a foreigner as a domestic tax payer. In this case it doesn't matter if the asymmetry at the corporate level is reversed at the personal level. In the case of perfect capital mobility, savings and investment decisions are totally separated and any distortions to the corporate tax system remains, independent of the personal tax system. It is therefore reasonable to assume that the debt - equity asymmetry is far more distortive today than 20 years ago, due to increased capital mobility.

\subsection{Investments and financial distortions}

The bias towards favoring debt over equity causes several problems. One problem is that it distorts financial decisions. Debt becomes the favored source of finance and equity bears the total burden of the corporate tax. This discrimination may have real effects 
Nordic Tax Journal 2014:2

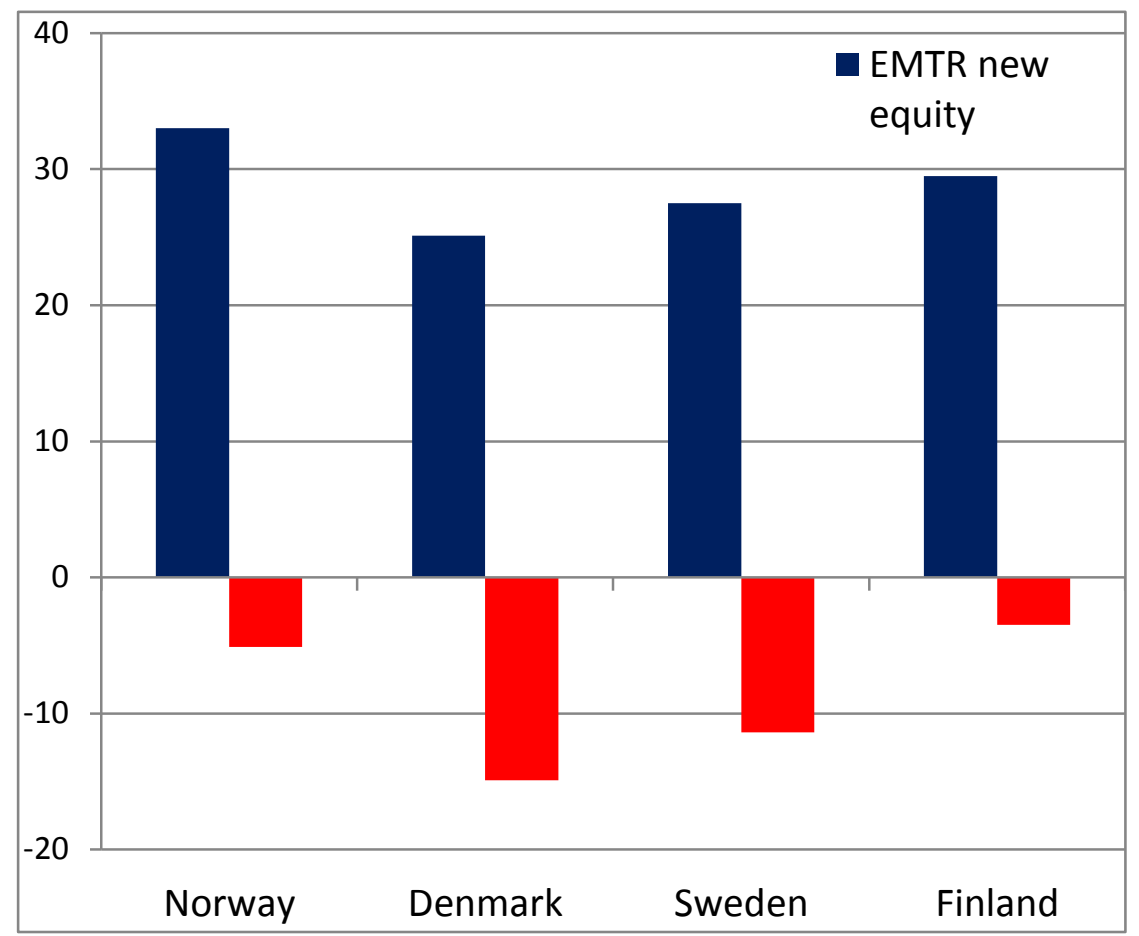

Figure 6: Effective marginal tax rates on equity and debt financed investments. Corporate level. 2012

Source: Spengel et al. (2012)

84 Benn Folkvord E Michael Riis Jacobsen 


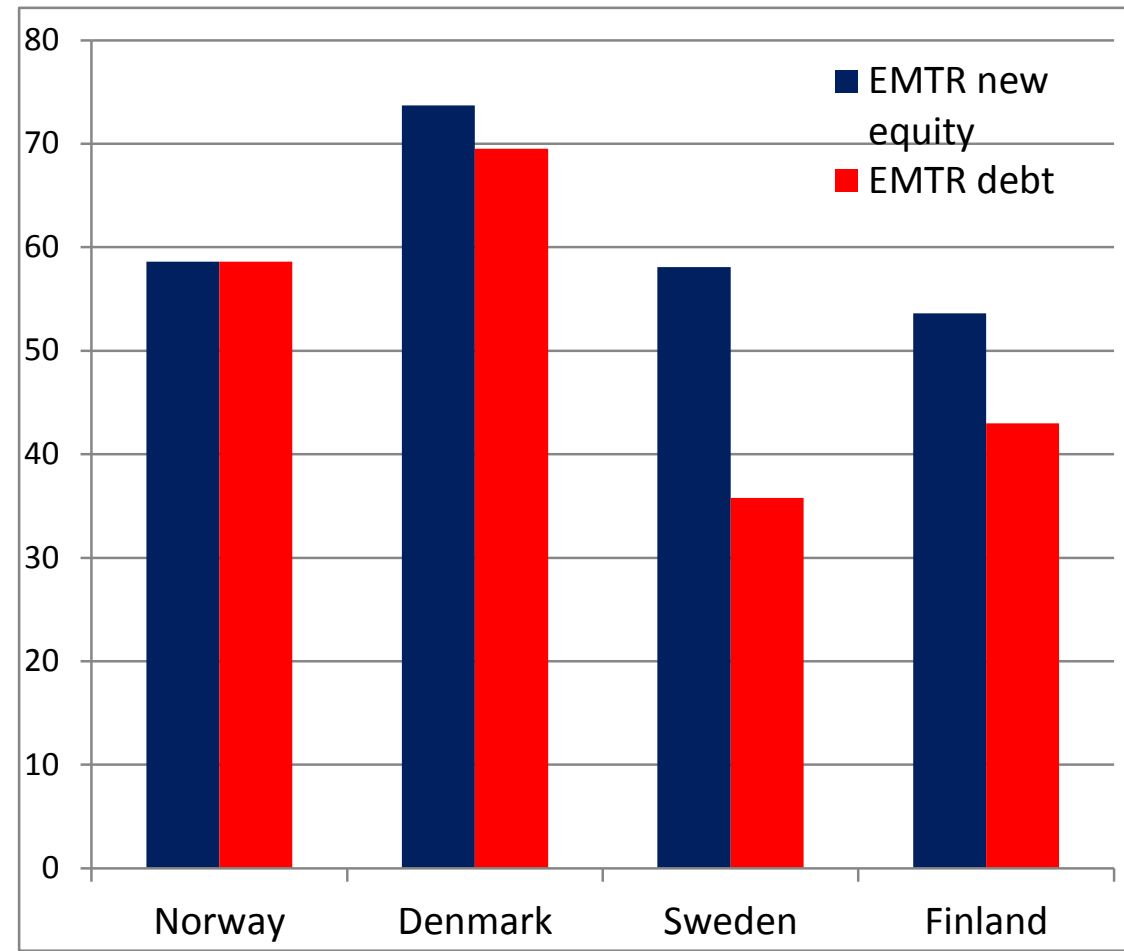

Figure 7: Effective marginal tax rates on equity and debt financed investments. Shareholder level. 2012

Source: Spengel et al. (2012)

because it is profitable for firms to undertake debt financed investments, even if they yield a pre-tax return below the pre-tax return of an equity financed investment. Sørensen (2010) estimates this welfare loss to be approximately SEK 7.2 bn in Sweden, or approximately 8.7 per cent of the corporate taxes paid by widely held Swedish corporations.

\subsection{Thin capitalization and profit shifting}

Another problem with asymmetric treatment of debt and equity is that it motivates profit shifting through thin capitalization. Multinationals can transfer profits from affiliates in high tax countries to low tax countries, in the form of interest payments on intra group loans. This problem is at the core of the BEPS-work in the OECD and a constant nuisance to tax authorities with moderate or high tax rates. Most OECD countries have specific (and/or general) tax measures to avoid profit shifting through thin capitalization (see chapter 4 for an overview over thin capitalization rules in the Nordic countries). Thin capitalization rules are often targeted at the level of allowed debt or level 
of deductible interest rates. The problem with such rules is that they are often insufficient, inaccurate or both, thus in itself creating distortions to the tax systems.

There are several models on the table in the international corporate tax debate that are aimed to treat debt and equity equally. There are two main types of models; one type that deny interest deductions (CBIT) and one type that allows deduction for the capital cost of equity (ACE). It is outside the scope of this report to give a thorough discussion of these models, but it is a fact that some of the Nordic countries are discussing these kinds of models in order to remove the debt - equity asymmetry. In Norway the ACE model has been raised in the public tax debate, and the Scheel-commission has been given a specific task in their mandate to investigate the ACE-model.

The Swedish national report is analyzing the efficiency effect of a neutral treatment of debt and equity, by abolishing interest deductions (a CBIT-type model). It investigates the impact of a sector's usage of debt capital and its effect on corporate taxes paid by that sector. The report finds that a considerable part of the variation of corporate income tax payments can be explained by sectors' average leverage. Furthermore, the report concludes that if all interest rate deductions where abolished in the corporate sector, the corporate income tax could be reduced by 6 per centage points without losing any revenue in static terms (Thomann 2014).

A Swedish tax committee on corporate taxation has proposed a CBIT-type of model in Sweden that denies deduction for net financial costs, combined with a in the reduction in the corporate tax rate from 22 to 16,5 per cent (SOU 2014: 40). 


\section{References}

Andersen, T.M., et al. (2007), "The Nordic Model - Embracing Globalisation and Sharing Risks, The Research Institute of the Finnish Economy, ETLA B232.

Bucovetsky, S. and J.D. Wilson (1991), Tax Competition with Two Tax Instruments", Regional Science and Urban Economics, 21, 333-350.

Chen, D. and J. Mintz (2012), “2012 Annual Global Tax Competitiveness Ranking - A Canadian Good News Story", SPP Research Paper, Vol. 5 Issue 28.

Diamond, P. and J. Mirrlees (1971), “Optimal Taxation and Public Production I Production efficiency" American Economic Review 61, 8-27.

SOU 2014: 40 "Neutral bolagskatt - för ökad effektivitet och stabilitet"

Spengel, C. et.al. (2012), "Effective Tax Levels using the Devereux/Griffith Methodology", Project for the EU Commission 2012, TAXUD/2008/CC/099

Sørensen, P.B. (2007), "Can capital income Taxes Survive? And Should They?”, CESifo Economic studies, Vol. 53 2/2007, 172-228.

Sørensen, P.B. (2010), "Swedish Tax Policy: Recent trends and Future Challenges", ESO 2010: 4.

Tropina, J. et al., (2010), "Tax Income Differences between Multinational and Domestic Corporations in Norway: A Panel Data Approach", SNF project no 1185 "Profit Shifting in Norway: A Theoretical and Empirical Analysis".

Thomann, C. (2014), "Recent developments in Corporate Taxation in Sweden", Nordic tax Journal (forthcoming).

Wilson, D.E. (1986), “A Theory of Interregional Tax Competition”, Journal of Urban Economics, 95, 835-56.

Zodrow, G.R., and P. Mieszkowski (1986), "Pigou, Tiebout, Property Taxation, and the Underprovision of Local Public Goods", Journal of Urban Economics, 19, 356-70. 